\title{
A review of Palaearctic Gymnophora Macquart (Diptera: Phoridae), with description of new species
}

\author{
MikHaIL B. MOSTOVSKI ${ }^{1}$ and Marina V. MIKHAILOVSKAYA ${ }^{2}$ \\ Paleontological Institute, 123 Profsoyuznaya Street, Moscow, 117997 Russia; e-mail: phorids@hotmail.com \\ ${ }^{2}$ Mountain-Taiga Station, Far Eastern Branch of Russian Academy of Sciences, Gornotayozhnoe, Maritime Territory, 692533, \\ Russia
}

Key words. Taxonomy, Phoridae, Gymnophora, Palaearctic, new species, new synonymy, lectotypes, distribution

\begin{abstract}
Palaearctic species of the genus Gymnophora are reviewed. Four new species, G. amurensis sp. n., G. gornostaevi sp. n., G. perpropinqua sp. n., and G. victoria sp. n., are described from the European Russia, Middle Asia, and Russian Far East. Females of two other species from the Far East are described under code letters. G. laciniata Michailovskaya, 1997 is synonymised under $G$. prescherweberae Disney, 1997. Lectotypes of G. arcuata (Meigen, 1839) and G. verrucata (Schmitz, 1929) are designated. The latter species is redescribed. Palaearctic females of $G$. nigripennis demonstrate wide variation of taxonomically important features and may, in fact, represent a group of closely related species. One female of $G$. nigripennis, which has been caught alive, is recorded to be infected with fungi.
\end{abstract}

\section{INTRODUCTION}

The genus Gymnophora Macquart, 1835 comprises more than 50 species recorded from the Holarctic and Oriental regions. European species are covered by Disney (1983, 1997), and Asian species have been treated by Brown (1987, 1988), Liu (1993), and Michailovskaya (1997). However, this genus is still poorly known in the Palaearctic Region. In this paper, we are reviewing Palaearctic species of this genus, with special reference to the territory of Russia and allied countries. Japanese species are satisfactory keyed and illustrated by Brown (1988), and we do not include them unless they are recorded from the mainland.

Representatives of the genus Gymnophora have quite distinctive general appearance and are easily recognisable under low magnification by the reduced frontal, thoracic and costal setation, the slender hind legs with the tibiae lacking of a longitudinal hair palisade, and the large wings (except in the brachypterous $G$. lapidicola) with a peculiar venation. Male hypopygium is usually withdrawn into the abdomen and circumverted $90^{\circ}$ counterclockwise. Biological data on Gymnophora are scarce and summarised recently by Brown (1998).

\section{MATERIAL AND METHODS}

Females of Gymnophora were studied mounted on slides as has been proposed by Disney (1983). Males were soaked in cold $10 \%$ solution of $\mathrm{KOH}$ for several hours, then rinsed in water and alcohol and transferred to a drop of glycerol for further study. Permanently, they are stored in pinned microvials Occasionally, males have been mounted on slides similarly to females. The drawings were made in transmitted light using a Leica DMLB microscope with drawing attachment.

Terminology of the structures of the aedeagal complex follows Brown (1987), although a different opinion has been expressed on the homology of some structures (Disney, 1999). Abbreviations of abdominal tergites and sternites appear as $\mathrm{T}$ and $\mathrm{S}$ respectively, with figures indicating the number of an abdominal segment. Wing terminology follows Disney (1994).

Material studied is kept in the following collections: Zoological Museum, Cambridge, UK - CMZ, Zoological Institute, St. Petersburg - ZIN, Zoological Museum of Moscow University - ZMMU, Institute of Biology and Pedology, Vladivostok IBP, Museum National d'Histoire Naturelle, Paris - MNHN, Los Angeles County Museum, USA - LACM, Zoologisches Forschungsinstitut und Museum Alexander Koenig, Bonn ZFMK, Zoological Museum of University of Helsinki - ZMUH, collection of the first author - MBM, collection of the second author-MVM.

\section{TAXONOMY}

\section{Gymnophora amurensis sp. $\mathrm{n}$.}

(Figs 4-7)

Diagnosis. Strong mediolaterals absent. Notopleural ridge pale brown. Costa without abrupt thickening before $\mathrm{R}_{1}$. Posterior margin of left side of epandrium without lobes or incisions. Left side of hypandrium with small process.

Etymology. From Amur region.

\section{Description}

Male. Body length $3.55 \mathrm{~mm}$. Third antennal segment brown. Palpi brown, slightly broadened, with 3 apical and ventro-apical bristles, most apical of which is longest and exceeds maximum palpus breadth. Additionally, there are numerous ventral and lateroventral hair-like bristles. Mediolaterals similar to adjacent hairs. Notopleural ridge pale brown. Legs yellowish brown. Wing length 3.45 mm. Costal index 0.52. Costal ratios 7:1.05:1. Costa just slightly gradually thickened before $R_{1}$. Axillary ridge with 2 bristles. Halteres pale yellow. Abdominal venter bare, except for segment 6 , where small hairs form a transverse patch at middle of posterior margin; few hairs just below T6. Tergites with scattered small hairs, which 

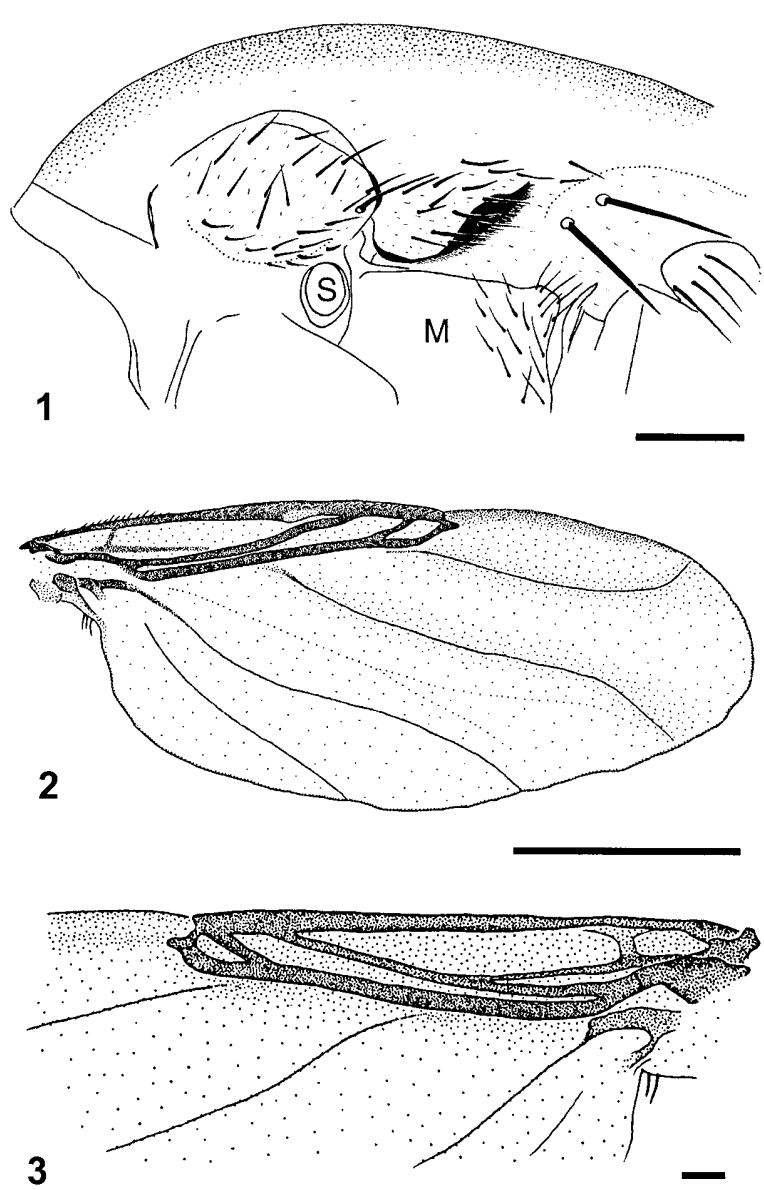

Figs 1-3. Thorax and wing details of Gymnophora. 1 - left face of thorax of $G$. healeyae, showing dark notopleural ridge; 2 - wing of $G$. verrucata; 3 - wing base of $G$. victoria sp. n. Abbreviations: $\mathrm{S}-$ anterior spiracle, $\mathrm{M}$ - mesopleuron. Scale: $0.1 \mathrm{~m}$ in Figs 1,$3 ; 1 \mathrm{~mm}$ in Fig. 2. (Fig. 1 courtesy of Dr. R.H.L. Disney) are remarkably longer in posterior half of T6. Posterior margin of left side of epandrium oblique, with bristles arranged in row on prominent ridge (Fig. 4). Right side of epandrium with knob-like posteroventral lobe bearing bristles and curly hairs (Fig. 5). Left side of hypandrium with small scoop-like process (Fig. 6), right side of hypandrium simple. Ring of basiphallus somewhat elongated (Fig. 7). Cerci moderately long. Hypoproct somewhat elongated.

Type material. Holotype, $\widehat{\delta}$, Russia, Amur Region, Zeya, 30.vii.1978 (A. Shatalkin) (ZMMU).

\section{Gymnophora arcuata (Meigen, 1830)}

(Figs 8, 9, 65)

Diagnosis. Mediolaterals differ from adjacent hairs, but much weaker than bristles on vertex. Notopleural ridge pale. Costa abruptly thickened before $\mathrm{R}_{1}$, with clear spot. Wing length of specimens from European Russia 2.9-3.9 $\mathrm{mm}$, that of West European specimens 2.4-3.8. Mean costal index 0.51 , range $0.49-0.54$. Mean costal sections ratio $6.38: 1.40: 1$, range 5.30-7.44:1.06-1.69:1. Left side of epandrium with small anteroventral lobe (Fig. 8). Left side of hypandrium with long process, which is greatly swollen at mid-length (Fig. 9). Female with T4 and T5 entirely absent, sclerotised glands absent. Apex of female abdomen with paired ventral sclerites, which are somewhat elongate and bear numerous (mean 30, range 24-37) setae grouped mainly along outer margin of sclerite (Fig. $65)$. Cerci on average 6.3 times as long as broad, range 6-7.

Type material examined. Lectotype (here designated), 오 rectangle printed label "Museum Paris coll. Meigen", small disc "2892 40" and "Meigen" on reverse side [handwritten], rectangle label "Phora arcuata $\%$ " [handwritten], rectangle label "arcuata Becker vidit 1898", and small green rectangle "98". Paralectotype, ㅇ, small disc "2892 40" and "Meigen" on reverse

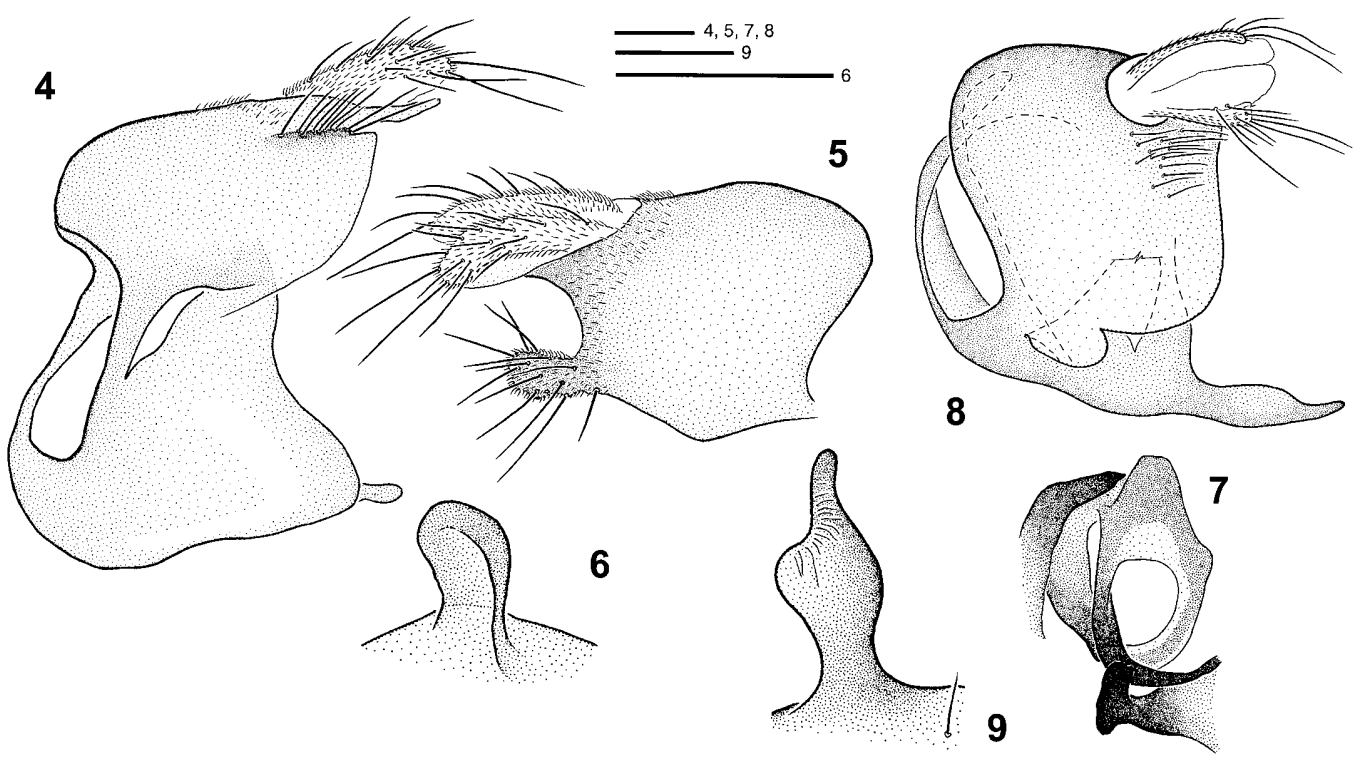

Figs 4-9. 4-7 - Details of hypopygium of G. amurensis sp. n.: 4 - left face of hypopygium; 5 - right face of epandrium; 6 process of left side of hypandrium; 7 - ring of basiphallus; 8-9-G. arcuata, left face of hypopygium and process of left side of hypandrium. Scale: $0.1 \mathrm{~mm}$. 
side [handwritten], rectangle label "Phora arcuata $q$ " [handwritten], and small green rectangle " 77 ".

Other material examined. England: $1+$, Surrey, Stepping Stones, 13.vii.1978, 1\%, Leicestershire, Swithland Wood, 27.vii.1979 (P. Chandler), 1 , Windsor Forest, 11.viii.1979 (P. Chandler), 1, Isle of Wight, Waller's Copse, 2.vii.1980 (P Chandler), 1 5 , North Yorkshire, Escrick Estate, vii.1990 (M Usher) (CMZ); France: 1\%, St. Augustin, 20.vi.1993 (L. Matile); Italy: 1 \&, 1 ㅇ, Aosta, Champlong Dessus, alt. $1000 \mathrm{~m}$, 17-21.vii.1984 (L. Matile), 1\%, Aosta, Villeneuve Bertolar, alt. 800 m, 16.ix.1974 (L. Matile); Romania: 13, 2 ㅇ, Comana Forest, 11.x.1968 (L. Matile) (MNHN); Ukraine: $1 \_$, Carpathians, $\mathrm{nr}$ Dubrinich, forest $\mathrm{nr}$ Lyuta village, 13.vii.1972 (V. Kovalev), 1o, Transcarpatian, Ugol'ka, fagetum, 15.viii.1987 (V. Kolyada) (ZMMU), 1, Kiev, Kadetskaya roshcha, 25.v.1903 (Yu. Vagner) (ZIN); Russia: $1 \delta$, Leningrad Region, Tolmachevo, 29.vii.1936, 1ㅇ, same data, 7.vii.1937 (Stackelberg), 1, NW Russia, vic. Luga, Tolmatschevo, 15.vii.1937 (Stackelberg) (ZIN), 19, Moscow Region, Abramtsevo, $28 . v i .1967$ (D. Ussatchev), 1 , Moscow Region, Golitsyno, 31.vii.1977 (A. Shatalkin), 1\%, same data, 9.ix.1978 (A. Shatalkin), 1q, Moscow Region, Vel'yaminovo, $30 \mathrm{~km}$ SSE of Domodedovo, 28.vi.1988 (A. Antropov) (ZMMU), 2子, 3 ㅇ, Moscow Region, Malakhovka, 24-28.vii.1994 (Mostovski), 1 , Moscow Region, nr Stupino, 21.vii.1994 (V. Kolyada) (MBM), 1§, Yaroslavl', Berditsyno, apple tree, 27.viii.1906 (A.N. Yakovlev) (ZIN), $10^{\circ}$, Yaroslavl', 12.viii.1977 (A. Shatalkin); Georgia: 1옹 Sukhumi, Aliz. gorge, 29.x.1953 (Borutskij) (ZMMU).

Distribution. Europe, Caucasus.

Comments. The greatly swollen process of the left side of the hypandrium is the most distinctive feature of the males of this species. However, we found that rarely this process is less swollen and may be easily confused with that of G. perpropinqua sp. n. In this case one should refer to the ventral lobe of the left side of the epandrium, which is much smaller than in $G$. perpropinqua sp. n. Females of arcuata are very similar to those of $G$. perpropinqua. Meigen (1830) described $G$. arcuata based on two females, but did not designate the holotype. To clarify the identity of this species, we have re-examined the syntypes and designated the lectotype and paratype. The type locality cannot be determined from the label data, although Macquart (1835), who erected the genus Gymnophora with $G$. arcuata as the type species, noted that this species is distributed in the northern France and northern Germany.

\section{Gymnophora fastigiorum Schmitz, 1952}

(Figs 10, 36)

Diagnosis. Strong mediolaterals absent. Notopleural ridge dark. Costa without abrupt thickening before $\mathrm{R}_{1}$. Left side of epandrium with nearly straight or just slightly concave posterior margin, with about ten bristles, and with small rounded elaboration on inner surface. Left side of hypandrium without process. Male cerci short. Female abdomen with T4 absent, T3 and T5 reduced, T7 watchglass-shaped, T8 triangular. Sclerotised glands absent, ventral apical sclerite unpaired.

Material examined. Russia: $5 \hat{\jmath}$, Buryatiya, Vitim R., Baissa, 15-25.vii.1997 (Mostovski) (MBM), 1ð, Magadan Reg., SibitTyellakh, Aborigen, 16.viii.1980 (Antonova) (ZMMU), 4 $\delta$,
Kamchatka, 18 km NO Kozyrevsk, 21.vii.1985 (Zlobin) (ZIN), 1ठ, Amur Region, Zeya, 13.vii.1978 (A. Shatalkin), ‡, Southern Maritime Territory, $40 \mathrm{~km}$ SE of Ussurijsk, 12.vii.1987 (A. Ozerov) (ZMMU), 7ð, Maritime Territory, 18 $\mathrm{km}$ SE of Ussurijsk, Gornotayozhnoe, 21-27.vi.1996 and 5-8.vii.1996 (M. Michailovskaya) (MVM).

Distribution. Russia: East Siberia, Japan, North America.

\section{Gymnophora gornostaevi sp. $\mathbf{n}$.}

(Figs 11-13, 37, 50)

Diagnosis. Mediolaterals weak. Notopleural ridge dark. Costa abruptly thickened and with clear spot. Posterior margin of left side of epandrium bilobed. Hypoproct longer than cerci, widened distally. Female abdomen with T5 absent and T4 greatly reduced. Sclerotised glands clearly visible, ventral apical sclerites paired.

Etymology. This species is named in the memory of Dr G.N. Gornostaev (Moscow State University).

\section{Description}

Body entirely dark brown, body length 3.2-3.64. Third antennal segment brown. Palpi brown, with 3-4 strong bristles, which are clearly longer than maximum palp breadth. Mediolaterals at least 2 times as long as adjacent hairs, but remarkably weaker than bristles on vertex. Notopleural ridge dark. Legs brown. Wing length 2.2-4 mm. Mean costal index 0.44 , range $0.41-0.46$. Mean costal sections ratio $6.27: 1.88: 1$, range 5-7:1.2-2.25:1. Costa with abrupt thickening before $R_{1}$ enclosing clear spot. Axillary ridge with one or two bristles. Halteres brown. Wing membrane grey brownish.

Male. Abdominal tergites with scattered short hairs, venter bare except segment 6 , which bears longish hairs at rear. Posterior margin of left side of epandrium with two small and broad lobes, upper lobe triangular, lower one rounded (Fig. 11). Right side of epandrium narrow with several rather strong bristles, its posterior margin with distinct notch (Fig. 12). Basiphallus well sclerotised, roughly rounded (Fig. 13). Distiphallus with well sclerotised base, anterior lobe of distiphallus extremely long and narrow, and bent downwards. Right side of distiphallus with well sclerotised short process, which is slightly arched. Cerci somewhat elongate. Hypoproct longer than cerci, notably broadened distally, its hind margin with small excavation and one strong bristle.

Female. Abdominal T2 broad trapezoidal, nearly rectangular, T3 semicircular, T4 and T5 absent or greatly reduced, T6 with several short hairs, which are longer at posterior margin. Segment 7 with numerous longish hairs, which are even longer at rear. T7 wedge-shaped with broad base and a few longish setae in distal portion (Fig. 37), S7 developed as long narrow sclerotised stripe. T8 blunt triangular with scattered setae (Fig. 50). Abdominal glands strongly sclerotised. Cerci 4.5 times as long as broad, range 3.9-5.1. Apical sclerites rounded, paired.

Type material. Holotype, 3 , Kirgiziya, Chatkalskij Mountain Ridge, Sary-Chilek, 29.V.1952 (L. Zimina). Paratypes, 3 $\circ, 2$, same data, 5s, same data except (Zhelokhovtsev), $1 \%$, same data except Arkit, 6.VI.1952 (L. Zimina). All types in ZMMU. 

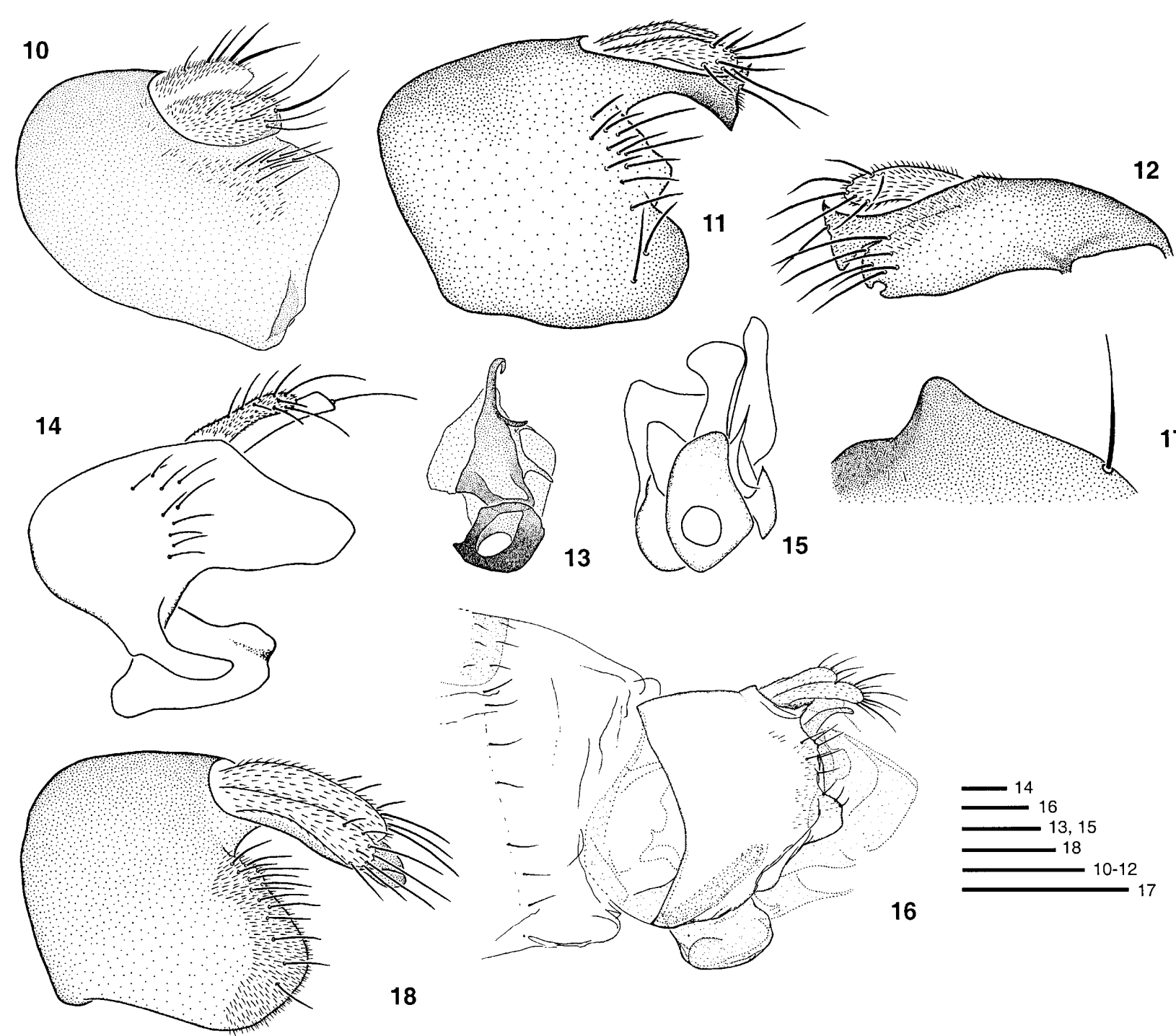

Figs 10-18. 10 - G. fastigiorum, left face of epandrium; 11-13-G. gornostaevi sp. n.: 11 - left face of epandrium; 12 - right face of epandrium; 13 - aedeagal complex; 14-15-G. gotoi, left face of hypopygium and aedeagal complex; 16-17-G. healeyae, left face of hypopygium and process of left side of hypandrium; 18 - G. integralis, left face of epandrium. Scale: $0.1 \mathrm{~mm}$. (Figs 14 , 15 courtesy of Dr. B.V. Brown, Fig. 16 courtesy of Dr R.H.L. Disney)

\section{Gymnophora gotoi Brown, 1988}

(Figs 14, 15, 38, 51)

Diagnosis. Strong mediolaterals absent. Notopleural ridge dark. Costa gradually thickened and without a clear spot. Left side of epandrium with notably drawn posterior margin and thin and narrow ventral process. Ring of basiphallus massive, with small aperture. Left side of hypandrium with small broad process. Male cerci somewhat elongate. Female T7 wedge-shaped, with massive proximal portion, T8 elongate with somewhat tapered posterior end and several hairs. Sclerotized glands absent. Abdominal venter with paired apical sclerites.

Material examined. Russia: $3 q$, Maritime Territory, $18 \mathrm{~km}$ SE Ussurijsk, Gornotaezhnoe, 17-22.vii.1996 and 28-31.vii.1996 (M. Michailovskaya) (MVM).

Distribution. Russian Far East, Japan.

\section{Gymnophora healeyae Disney, 1980}

(Figs 1, 16, 17, 39, 52)

Diagnosis. Mediolaterals developed but clearly shorter than bristles on vertex, especially in females. Notopleural ridge dark. Costa abruptly thickened before $\mathrm{R}_{1}$, but without clear spot. Left side of epandrium with small posteroventral lobe and several bristles along posterior margin. Left side of hypandrium with prominence. Female abdomen with $\mathrm{T} 3$, but $\mathrm{T} 4$ and $\mathrm{T} 5$ reduced, abdominal glands poorly sclerotised, abdominal venter with paired apical sclerites.

Type material examined. Holotype, 1 s, England, Bear Park, 10.viii.1978 (Coulson). Paratypes, 3 \% , Rowantree Scar, Yorkshire, 23.ix.1976 (Coulson), 1, Salt Lake Quarry, North Yorkshire, 1.vii.1977 (Disney), 1ㅇ Waskerley Beck, 30.vii.1976 (Coulson). The types housed in CMZ. 


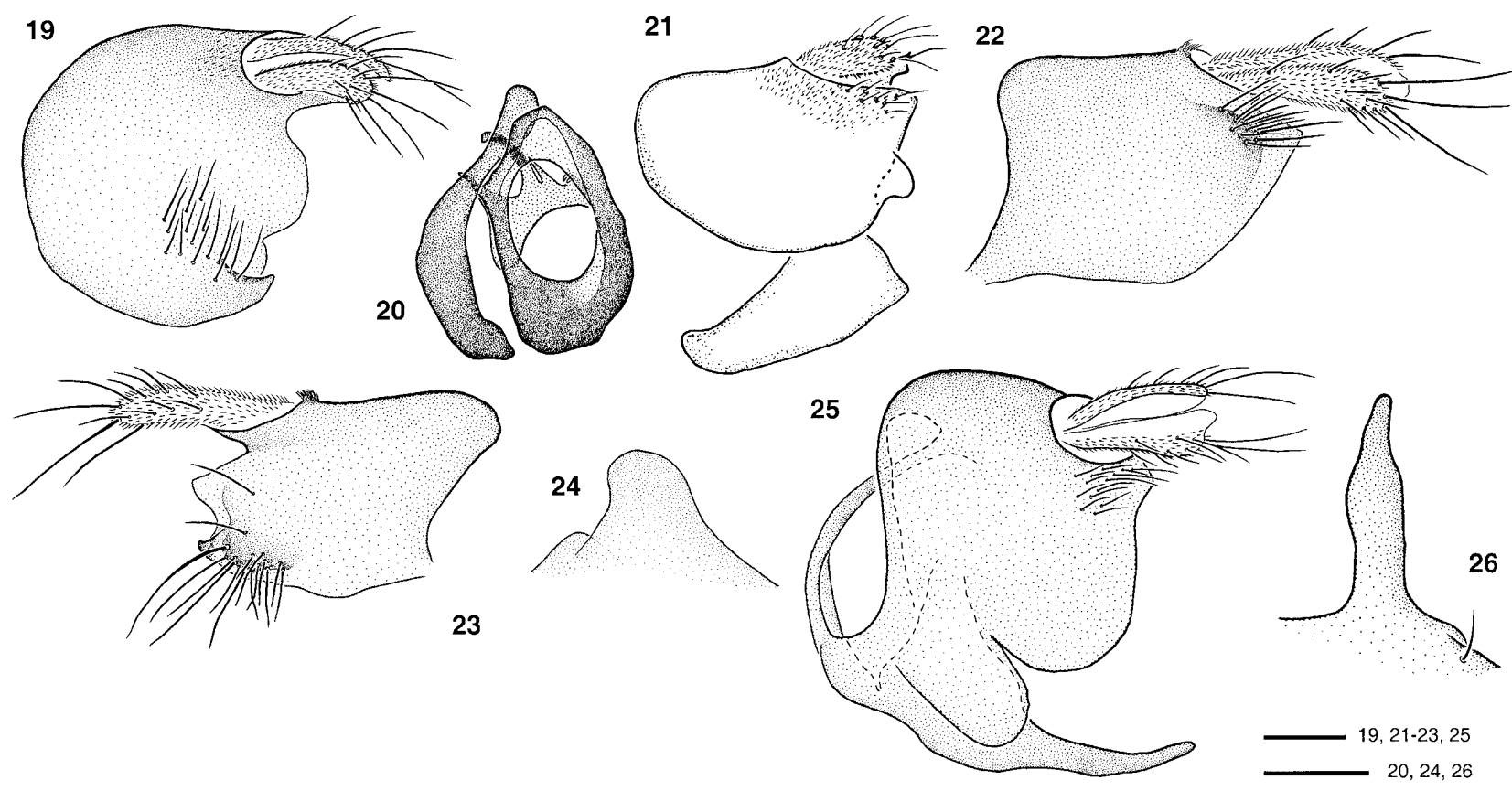

Figs 19-26. 19-20 - G. multipinnacula, left face of epandrium and details of aedeagal complex; 21 - G. nigripennis, left face of hypopygium; 22-24 - G. pararcuata: 22-23 - let and right faces of epandrium; 24 - process of left side of hypandrium; 25-26-G. perpropinqua sp. $\mathrm{n}$., left face of hypopygium and process of left side of hypandrium. Scale: $0.1 \mathrm{~mm}$. (Fig. 21 courtesy of Dr. B.V. Brown)

Other material examined. England: $10,2 q$, Dun Fell 1700', 2.viii.1978 (Coulson), 1ठ, Newby Head, 11.viii.1978 (Coulson) (CMZ).

Distribution. England.

\section{Gymnophora integralis Schmitz, 1920}

(Figs 18, 40, 41, 53)

Diagnosis. Mediolaterals at most just little longer than other hairs on frons in both sexes. Notopleural ridge dark. Costa with abrupt thickening, enclosing clear spot. Posterior margin of left side of epandrium notably convex and fringed with bristles and hairs. Left side of hypandrium with large parallel-sided process. Hypoproct longer than cerci. Female abdomen with all tergites fully developed, a pair of sclerotised glands that discharge into a common chamber, whose opening to the exterior is enlarged and transversely elongated. Abdominal venter with paired apical sclerites.

Material examined. Romania: 19 , Banat, env. de-Baine Herculane, 6.x.1968 (L. Matile) (MNHN); Russia: 1, Belgorod Region, 20-30.iv.1987 (V. Kolyada) (MBM), 32 o, 15 q, Maritime Territory, $18 \mathrm{~km}$ SE of Ussurijsk, Gornotayozhnoe, 30.iv-3.vi.1996 (M. Michailovskaya) (MVM). Additionally, one slide-mounted male from Schmitz' collection (ZFMK) has been studied and figured; this slide has no data labels.

Distribution. Europe, Russian Far East, Japan. This may turn to be transpalaearctic species.

\section{Gymnophora multipinnacula Brown, 1987}

(Figs 19, 20, 42, 54)

Gymnophora verrucata Michailovskaya, 1997: 3 non Schmitz, 1927 (misident.).
Diagnosis. Mediolaterals distinctive but remarkably smaller than bristles on vertex. Notopleural ridge dark. Costa with abrupt thickening before $\mathrm{R}_{1}$ and encloses clear spot. Left side of epandrium with irregular posterior margin and bristles concentrated in the lower part. Left side of hypandrium without process. Inner left arm of aedeagus with five to six peaks, which are clearly visible on prepared hypopygium. Female abdomen with T3 reduced, T4 and T5 absent, abdominal glands sclerotised and clearly visible. Abdominal venter with paired apical sclerites.

Material examined. Russia: 1 $\delta^{\star}$, Amur Region, Zeya, 5.vii.1978 (Belov), 1ठ, Maritime Territory, $40 \mathrm{~km}$ SE of Ussurijsk, 26.viii.1983 (A. Ozerov) (ZMMU), 11 đ 17오, Maritime Territory, $18 \mathrm{~km}$ SE of Ussurijsk, Gornotayozhnoe, 25.vii. and 18-31.viii.1996 (M. Michailovskaya) (MVM). Most of specimens were caught in copula.

Distribution. Russian Far East, Japan.

\section{Gymnophora nigripennis Schmitz, 1926}

(Figs 21, 43, 55, 56, 66, 67)

Diagnosis. Mediolaterals at most just slightly differ from adjacent hairs. Notopleural ridge dark. Costa gradually thickened before $\mathrm{R}_{1}$. Posterior margin of left side of epandrium oblique and has small elaboration. Left side of hypandrium without process. Male cerci short. Females with abdominal T4 absent. T3 and T5 developed but obviously less than T2 or T6, sometimes reduced to stripe or small patches or developed as semicircular sclerites. T7 narrow wedge-shaped, T8 elongate triangular to pentagonal. Abdominal venter with single apical sclerite, 
27

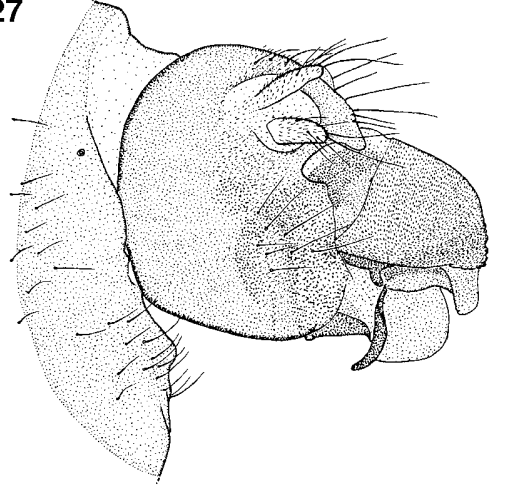

29

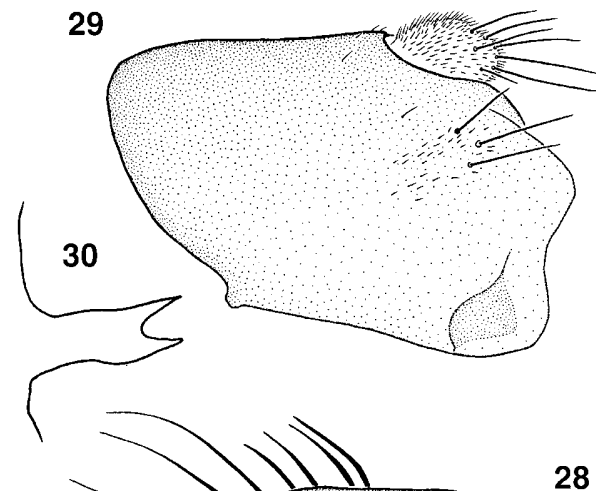

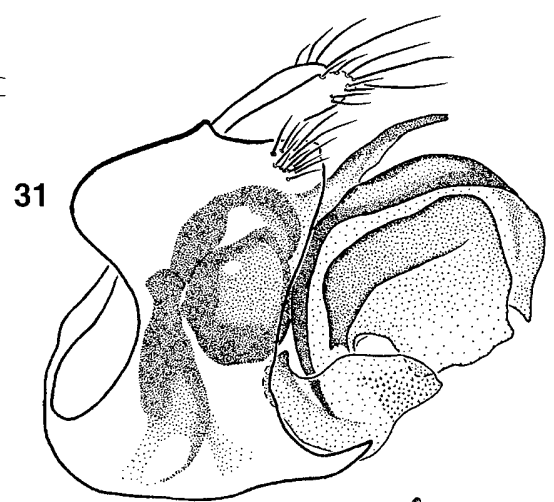

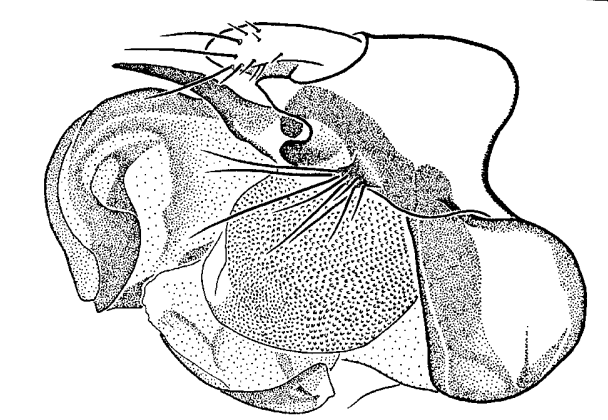

31-34

32
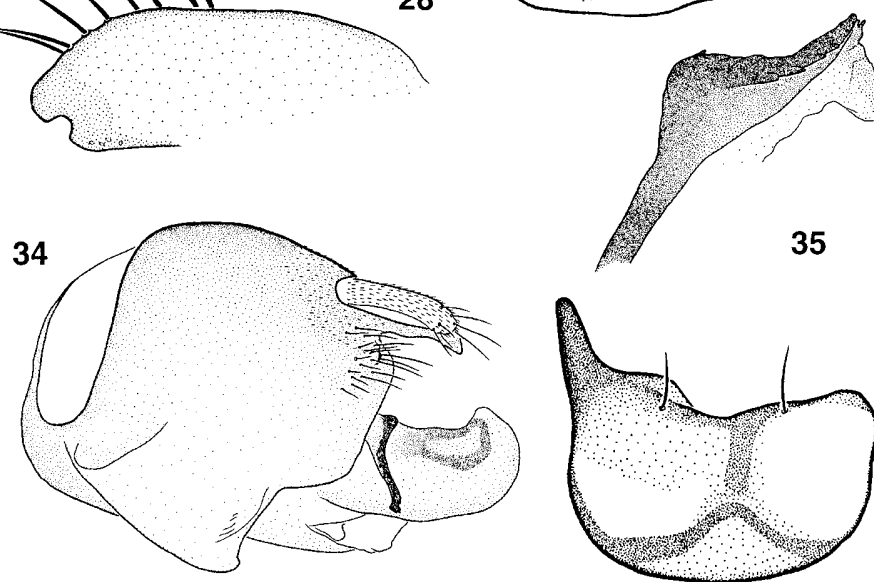

35

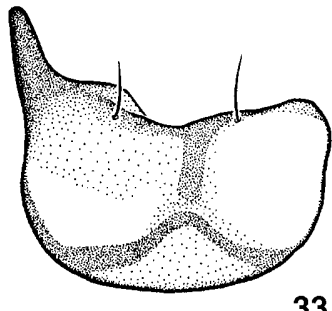

33

Figs 27-35. 27-28 - G. prescherweberae, left face of hypopygium and right side of epandrium from below; 29-30 - G. quartomollis, left face of epandrium and bifurcate process; $31-33-$ G. verrucata, left and right faces of epandrium and hypandrium from below respectively; 34-35-G. victoria sp. n., left face of epandrium and distiphallus. Scale: $0.1 \mathrm{~mm}$. (Fig. 27 courtesy of Dr. R.H.L. Disney)

bearing fan of long setae and short hairs between them. Sclerotised glands absent.

Comments. The recognition of this species is probably the most troublesome in the genus. Females of this species demonstrate wide variation of the shape of their tergite 8 (Figs 55, 56) and tergites 3 and 5. The female from the northern Maritime Territory seems to be the closest to European specimens, as evidenced by the shape of its abdominal tergites, the shape of the internal sclerotised ring, which is not bent, and the straight hairs between the setae on the apical sclerite of the abdomen. Other specimens from the Far East and China collected by Licent show other states of these characters. Their T5 developed as a semicircular sclerite (except for the specimen from Kamchatka, whose T5 is greatly reduced), the internal sclerotised ring is more or less bent, and the hairs on the apical sclerite is not straight but somewhat curly (Fig. 67). Chinese specimen collected by Przewalsky has the internal sclerotised ring being not bent and straight hairs on the apical sclerite, besides the semicircular T5. However, at the present state of knowledge all these differences seem to be insufficient to put these females as a separate species now, especially without a confident association with males. Brown (1988) reported some other unidentified females of $G$. nigripennis-subgroup from Japan, and female of $G$. nepalensis is still unrecognised
(Brown, 1988). On balance, we decided to keep these doubtful specimens under the name of $G$. nigripennis, but the reader should bear in mind that they may in fact belong to other species.

The female from the Kirov Region has been found to be filled with fungal hyphae that penetrate the whole body including the head and legs. This should be of particular interest, since this specimen was caught alive.

Type material examined. Holotype, $q$, "Museum Paris coll. Meigen" [printed], small disc " 2875 40" [handwritten], "Phora nigripennis" [handwritten], " 86 " [pale bown rectangular label]. The holotype is housed in MNHN.

Other material examined. Russia: $1 \%$, "Gouv. Petrograd, Tobzhitsa, 30.vi.1934" (Shtakelberg) (ZIN), 1\%, Vologda Region, Kich-Gorodetskij Distr., Sud. Gora village, 22.vii.1999 (Mostovski), 1\%, Kirov Region, Yug R., Bolsheromanovo, 4-6.viii.1994 (Mostovski) (MBM), 1 \%, Amur Region, Zeya, 26.vii.1979 (A. Shatalkin) (ZMMU), 1 丸, 1 \&, Kamchatka, Kamchatka R., Kamaki settlement, 9.vii.1909 (A. Derzhavin) (ZIN); China: 1\%, "montes Gan-ssu, China occid., Przewalsky, viii.[18]71" and "77442", 1\%, "Mae eull ting, 1.vii.[19]33, Licent", 19, "Mahochan, 15.vii.[19]18, Kansou O., Licent" (MNHN).

Distribution. Europe, Far East, China.

\section{Gymnophora pararcuata Brown, 1988}

(Figs 22-24, 44, 57) 
Diagnosis. Mediolaterals at most just differ from adjacent hairs. Notopleural ridge pale. Costa with abrupt swelling before $\mathrm{R}_{1}$ enclosing clear spot. Posterior margin of left side of epandrium oblique, bristles situated on wide tubercle. Right side with short hooked process oriented inwardly and bristles on posteroventral tubercle. Left side of hypandrium with short simple process. Cerci moderately elongated in males, hypoproct short. Female abdomen with $\mathrm{T} 4$ and $\mathrm{T} 5$ absent, and $\mathrm{T} 3$ greatly reduced if any, $\mathrm{T} 7$ wedge-shaped with notably concave anterior margin, T8 with asymmetrically developed anterior part. Abdominal venter with paired apical sclerites. Sclerotised abdominal glands absent.

Type material examined. Paratype, ${ }^{2}$, Japan, Fukuoka, Mt. Hikosan, 31.x.1973 (K. Takeno) (LACM).

Other material examined. Russia: 1 \%, Amur Region, Zeya, 1.ix.1979 (A. Shatalkin) (ZMMU), 3ð, 1, Maritime Territory, $18 \mathrm{~km}$ SE of Ussurijsk, Gornotayozhnoe, 17-24.vii.1996 (M. Michailovskaya) (MVM), 1\%, Maritime Territory, Lazo Reserve, 7.ix.1997 (MBM).

Distribution. Russian Far East, Japan.

\section{Gymnophora perpropinqua sp. $\mathrm{n}$.}

(Figs 25, 26, 45, 58, 68)

Diagnosis. Mediolaterals differ from adjacent hairs, but clearly weaker than bristles on vertex. Notopleural ridge pale. Costa with abrupt thickening that encloses clear spot. Left side of epandrium with well developed ventral lobe. Left side of hypandrium with long process, which is just slightly swollen at mid-length. Female abdomen with T4 and T5 absent and T3 somewhat reduced, T7 wedgeshaped, T8 broad watchglass-shaped, both $\mathrm{T} 7$ and $\mathrm{T} 8$ similar to those of $G$. arcuata. Abdominal venter with paired apical sclerites, which are rounded and with 21-27 setae that are not densely arranged along outer margin. Sclerotised abdominal glands absent.

Etymology. From Latin perpropinqua (very similar).

\section{Description}

Body length 2.4-3.2 mm. Third antennal segment brown. Palpi brown, not broadened, with several setae, which are clearly longer than maximum palpus breadth. Mediolaterals at least 1.5 times shorter than bristles on vertex. Notopleural ridge pale. Legs yellowish brown. Wing length $2.7-3.7 \mathrm{~mm}$. Mean costal index 0.49 , range $0.48-0.52$. Mean costal sections ratio $6.02: 1.35: 1$, range 5.1-7.71:0.9-2.08:1. Costa with abrupt thickening before $\mathrm{R}_{1}$, which encloses clear spot. Axillary ridge with two to three bristles. Halteres yellow.

Male. Abdominal venter bare, with exception of last segment, which bears extremely short scattered hairs at rear. Tergites with dispersed short hairs. Hypopygium similar to that of $G$. arcuata. However, epandrium with strongly developed ventral lobe (Fig. 25), and hypandrial process only slightly swollen at mid-length (Fig. 26). Cerci moderately long. Hypoproct short.

Female. All abdominal segments with scattered hairs, which are longer on 6-8 segments, especially along hind margin. Venter with longish hairs along hind margin of segments 6 and 7. T2 trapezoidal, T4 and T5 absent, T7 wedge-shaped (Fig. 45), S7 faint or absent, T8 watchglass-shaped (Fig. 58). Apical sclerites rounded, with 24 setae (range 21-27), which are more dispersed and not confined to outer margin of sclerite (Fig. 68). Cerci on average 5 times as long as broad, range 4.5-6. Sclerotised abdominal glands absent.

Type material. Holotype, $\delta$, Ukraine, Crimea, Bakhchisaraj Distr., Kayas-Dzhilga, 14.vi.1995 (Mostovski) (ZMMU). Paratypes. Ukraine: $20^{\circ}, 1 \%$, Crimea, Alushta, Chel'menchi R., 30.v.1995 (Mostovski), 1, 2 ㅇ, Crimea, Nikita, Botan. Garden, 31.v.1995 (Mostovski) (MBM), 3 0 , same data as holotype (CMZ), 2\#, same data as holotype except 26.vii.1995, $1 \%$, same data as holotype except 2.vii.1995, $2 \nrightarrow, 5 \%$, SW Crimea, Sel'bukhra Mt., 5.vi.1995 (Kolyada), 20, same data except 6.vi.1995 (Kolyada) (ZMMU), $1 \delta$, same data (Kolyada) (LACM), $1 \hat{z}$, same data (Kolyada) (ZFMK), 2 $\hat{\delta}$, same data (Kolyada) (ZIN), 2 \&, Crimea, Bakhchisaraj Distr., nr Prokhladnoe, Kizil-Chigir, 19.06.95 (Mostovski) (ZMMU), 1 f , Crimea, Bakhchisaraj Distr., Prokhladnoe, window 23.vi.1995 (Mostovski), 1 ว, 1 \% , Crimea, Bakhchisaraj Distr., Kertmel'skij, oak forest, 24.vi.1995 (Mostovski), $1 \delta$, Crimea, Bakhchisaraj Distr., Aksu-Dere, 25.vi.1995 (Mostovski), 3z, 29, Crimea, Bakhchisaraj Distr., nr Prokhladnoe, vi.1995 (Mostovski) (MBM), 29 same data (CMZ), 19 same data (LACM), 19 same data (ZFMK), 19 same data (ZIN); Russia: $1 \delta$, Moscow Reg., nr Stupino, 21.vii.1994 (Kolyada), 1 \&, 1, Kirov Reg. Jug R. Bolsheromanovo,1-9.viii.1994 (V. Kolyada), 10ํ, 1우, same data except 4-6.viii.1994 (Mostovski) (MBM).

Comments. This new species seems to be very closely related to $G$. arcuata. Even the aedeagal complexes are very similar in these species, although they usually differ in other closely related species. The most remarkable feature that distinguishes $G$. perpropinqua from $G$. arcuata is the process of the left hypandrial lobe, which is not swollen as much as the process of $G$. arcuata. Another character is the well developed ventral lobe of the left side of the epandrium. In females, the shape of T7 and T8 vary greatly in both species, and therefore they cannot be used as reliable characters for separation of these species. The only more or less reliable feature is the shape of the apical sclerites, and setation pattern of these sclerites. In the new species these sclerites are somewhat smaller, more rounded and have fewer setae, which are not arranged so densely along the outer margin as those in $G$. arcuata. Cerci are relatively shorter in $G$. perpropinqua. Differences between these two species are rather faint in the wing venation. However, the mean costal index is somewhat greater in specimens of $G$. arcuata that are to hand, and notably greater if one takes into account the figures obtained for European specimens by Brown (1987).

\section{Gymnophora prescherweberae Disney, 1997}

(Figs 27, 28, 46, 59, 69)

\section{Gymnophora laciniata Michailovskaya, 1997: 7, syn. n.}

Diagnosis. Mediolaterals notably strong, although they are obviously weaker than those on vertex. Notopleural ridge dark. Costa without abrupt thickening before $R_{1}$. Posterior margin of left side of epandrium without abrupt excavation or elaboration, process of right side of epan- 

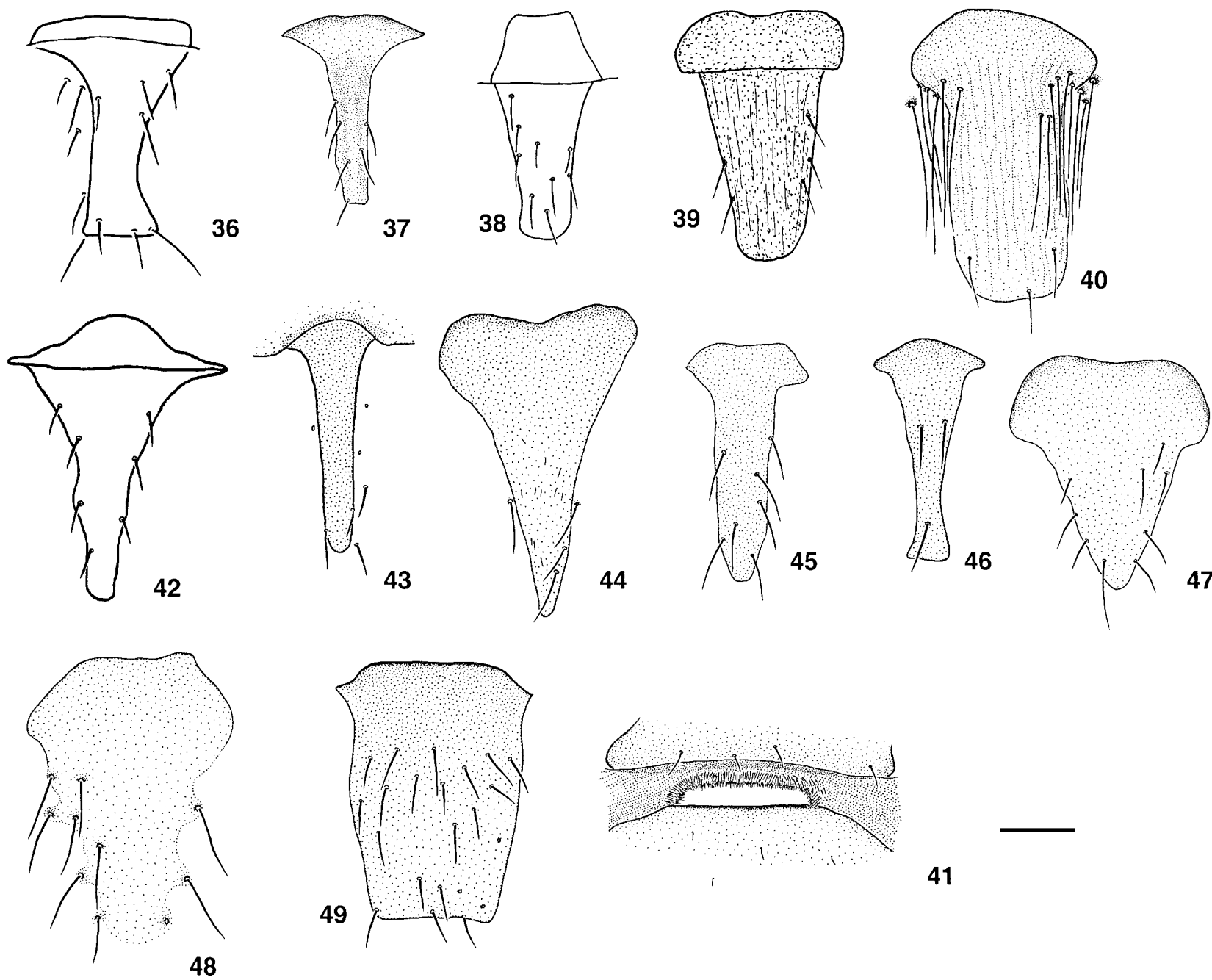

41

Figs 36-49. Female tergite 7 of Gymnophora spp. 36 - G. fastigiorum; 37 - G. gornostaevi sp. n.; 38 - G. gotoi; 39 - G. healeyae; 40 - G. integralis; 42 - G. multipinnacula; 43 - G. nigripennis; $44-$ - . pararcuata; $45-$ G. perpropinqua sp. n.; $46-G$. prescherweberae; $47-G$. victoria sp. n.; $48-G$. sp. A; $49-G$. sp. B; $41-G$. integralis, opening of abdominal glands between T5 and T6. Scale: $0.1 \mathrm{~mm}$. (Figs 36, 38 courtesy of Dr B.V.Brown, Fig. 39 courtesy of Dr. R.H.L. Disney)

drium with notch near its tip when viewed from below, and with bristles arranged in row. Left side of hypandrium without process. Cerci short. Female abdomen with T3-5 reduced, T7 approx. as long as broad, with numerous setae, T8 narrow wedge-shaped, with concave sides. Abdominal glands weakly sclerotised. Abdominal venter with paired apical sclerites, which are small and somewhat rounded.

Type material examined. Holotype, 0 , Thuringia, Appfelstadter Ried, grassland, 26.ix.1985 (J. Weipert) (CMZ). Paratypes. + , same data as holotype, $\delta$, $q$, same data as holotype except 1.vii.1985 (CMZ).

Other material examined. Russia: 1 ,, $\mathrm{M}$. Khekhtsir, $25 \mathrm{~km}$ $\mathrm{S}$ of Khabarovsk, 31.viii.1979 (Nartchuk) (ZIN), 60, Maritime Prov., $18 \mathrm{~km}$ SE Ussurijsk, Gornotaezhnoe, 12-12.vii and 24-26.vii.1996 (M. Michailovskaya) (IBP).

Distribution. Europe, Russian Far East.

Comments. This species was described nearly simultaneously from Germany and Russian Far East. The shape of both left and right sides of the epandrium and the pattern of setation support the newly proposed synonymy.

\section{Gymnophora quartomollis Schmitz, 1920}

(Figs 29, 30, 60)

Diagnosis. In males, mediolaterals clearly differ from adjacent hairs, but at least 2 times weaker than bristles on vertex, mediolaterals absent in females. Notopleural ridge dark. Costa gradually thickened before $\mathrm{R}_{1}$. Left side of epandrium with excavated posterior margin, with three to four bristles, and with small triangle elaboration on inner surface. Left side of hypandrium without process. Female abdomen with T4 absent and T3 reduced, T7 long, narrow, triangular, T8 pentagonal. Paired sclerotised glands absent, apical sclerite single.

Material examined. Ukraine: $1 \delta$, 1 , Crimea, Bakhchisaraj Distr., Sel'bukhra Mt., 5-6.vi.1995 (Kolyada), 1\%, same data except 15.vi.1995, 2 \%, Crimea, Bakhchisaraj Distr., Nauchnyj settlement, Kayas-Dzhilga, 23.vi.1995 (Mostovski) (ZMMU), 10, Crimea, Bakhchisaraj Distr., Aksu-Dere, 25.vi.1995 (Mos- 
tovski), 2‡, 6ㅇ, Crimea, Bakhchisaraj Distr., Kizil-Chigir, 19.vi.1995 (Mostovski) (MBM); Russia: 1 $\succsim$, Leningrad Reg., vic. Luga, Tolmatschevo, 20.vii.1935 (Stackelberg), 1 9 , Leningrad Reg., Luga, 12.viii.1954 (Stackelberg), 1\%, Leningrad Reg., Yashchera, 6.vii.1958 (Stackelberg), 1 \%, same data except 26.vii.1963, 1ㅇ, same data except 31.vii.1963 (ZIN), 1\%, Moscow Reg., Pavlovsk. Sloboda, vi.1987 (Kolyada), 53, 3 ㅇ, same data except 1-15.vii.1987, 2\$, Moscow Reg., v-vi.1988 (Kolyada) (ZMMU), 2‡, 5, Moscow Reg. Malakhovka, 24-28.vii.1994 (Mostovski), 1ठُ, same data except 9.ix.1994, 10, Moscow Reg., nr Stupino, 21.vii.1994 (Kolyada), 2 우, Moscow Region, v-vi.1994 (Kolyada), 1 \$, 1 \%, Belgorod Reg., 2.vii.1988 (Kolyada) (MBM).

Distribution. Europe.

\section{Gymnophora verrucata Schmitz, 1927}

(Figs 2, 31-33)

Diagnosis. Strong mediolaterals absent. Notopleural ridge pale. Costa with abrupt swelling and with clear spot. Left side of epandrium with oblique posterior margin and patch of short bristles. Left side of hypandrium with elongate process.

\section{Redescription}

Body length $3.6 \mathrm{~mm}$. Palpi dark with paler stem. Mediolaterals indistinct from other hairs. Notopleural ridge pale. Legs yellowish. Wing length $3.1 \mathrm{~mm}$ (Fig. 2). Costal index 0.55. Costal sections ratio 7.1:2:1. Costa with abrupt thickening, before $\mathrm{R}_{1}$ tip, that encloses clear spot. Wing membrane shadowed, tinged along fore margin and, to less degree, along first and second thin veins. Halteres pale yellowish. Left side of epandrium with posterodorsal bunch of bristles, which are not longer than longest bristles on cerci. Posterior margin of left side of epandrium oblique, without incisions or lobes (Fig. 31). Right side of epandrium with deep posterior notch and lateroventral lobe bearing fascicle of long and shorter bristles (Fig. 32). Left hypandrial lobe with moderately long process, only slightly narrowed apically (Fig. 33). Aedeagus enlaged, complex. Basiphallus massive, with small aperture. Anterior lobe of distiphallus broad and curved, resembling that of $G$. pararcuata in relative position to basiphallus, but more massive. Cerci somewhat elongate. Hypoproct short.

Type material examined. Lectotype (here designated), $\delta$ Russia, with labels "Ussuri: Spasskaja. 10.IX.1917. Y. Wuorentaus", "Gymnophora verrucata Schmitz \& Holotype" [Schmitz" handwriting], and "Mus. Zool. H: fors Spec. typ. No. 4713 Gymnophora verrucata Schmitz". The lectotype is housed in the ZMUH.

Other material examined. Russia: 1 ㅎ, Amur Region, $40 \mathrm{~km}$ W of Svobodnyj, Klimoutsy, oak forest, 9.ix.1958 (Zinoviev) (ZIN).

Distribution. Russian Far East.

Comments. The original description of this species is rather vague and insufficient to recognise it among other species. Schmitz (1927) noted that he based it on two specimens, a male and a female, but did not designate the holotype clearly. For a long time, the female was considered as the holotype and the male was thought to be lost (Brown, 1987; Michailovskaya, 1997). Meantime, the male with the original labels and Schmitz's handwriting has re-appeared in Helsinki and is designated here as the lectotype and redescribed. Unfortunately, we cannot find any traces of the female, the other syntype specimen, to designate it as the paralectotype.

\section{Gymnophora victoria sp. nov.}

(Figs 3, 34, 35, 47, 61)

Diagnosis. Rather strong mediolaterals present in males, but absent from females. Notopleural ridge dark. Costa without abrupt thickening. Left side of hypandrium with ventral lobe. Distiphallus indented. Female T7 wide wedge-shaped, T8 crescent. Abdominal venter with paired sclerites.

Etymology. From Latin victoria "victory", to commemorate the year of the victory in the World War II, when one of the paratypes was caught.

\section{Description}

Body length 3-4 mm. Third antennal segment brown. Palpi brown, slightly broadened, with several short apical setae, which are at most little longer than maximum palpus breadth. Notopleural ridge dark. Legs yellowish brown. Wing length 2.7-3.0 mm. Mean costal index 0.49 , range $0.47-0.50$. Mean costal sections ratio 7.6:1.6:1, range 5.0-9.0:1.2-2.1:1. Costa gradually and only slightly thickened before $\mathrm{R}_{1}$ tip (Fig. 3). Axillary ridge with two, rarely three or four fine bristles. Halteres grey brown.

Male. Abdominal tergites with scarce short hairs, abdominal venter bare, with exception of last segment, which bears short hairs at rare. Left side of epandrium with straight posterior margin, with broad triangle ventral process bearing poorly distinct tubercle (Fig. 34). Right side of epandrium similar to G. palmula (see Brown, 1998). Hypandrium nearly symmetrical from below. Distiphallus long, well sclerotised, foot-like, with obtuse dents along its posterior margin (Fig. 35). Cerci and hypoproct elongate.

Female. All abdominal tergites well developed, with scattered fine hairs. T7 large, wedge-shaped, broadened in anterior portion, with few longish setae (Fig. 47), S7 triangular or watchglass-shaped, sometimes developed as broad moderately sclerotised stripe, T8 small, crescent, with very few setae (Fig. 61). Venter of abdominal segment 8 with two small hairy sclerites. Abdominal glands well sclerotised, paired. Cerci 2.8 times as lond as broad, range $2.2-3.3$, often slightly pointed. Apical sclerites rounded rectangular.

Type material. Holotype, ¿, Kirgiziya, Batken District, Madygen, 16.v.1964 (Panfilov, Pritykina) (ZMMU). Paratypes. Turkmeniya: 1ô, 1요 Kopet-Dag, Firyuza gorge, 17.iv.1960 (Zhelokhovtsev), 1\%, Badkhyz, Akar-Cheshmy, 19.iv.1976 (V. Kovalev) (ZMMU); Uzbekistan: $1 \succsim, 3+$, Tashkent, aryk Bos-su, 25.iv.1925 (Dobrzhanskij); Kirgiziya: 1의 "Frunze (Pishpek), Semir., 10.v.931" (L. Zimin); Tajikistan: 1九, Kondara gorge, Varzoba village, $1100 \mathrm{~m}$ alt., 21.v.1939 (Gussakovskij), 2 3 , Stalinabad, Gul'bista R. valley, $20 . i v .1943$ (Stackelberg), 1o, 1ㅇ, Stalinabad, foothills, 18.iv.1943, 1q, same data, 22.iv.1945, 1 oे, same data, 2.v.1945 (Gussakovskij) (ZIN).

Distribution. Middle Asia. 


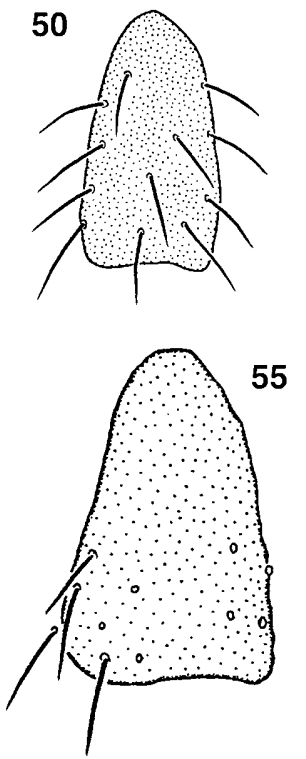

59

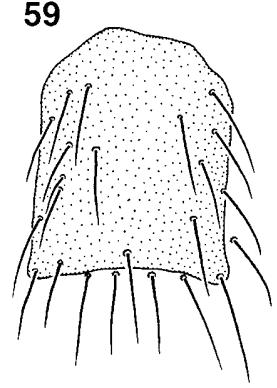

51

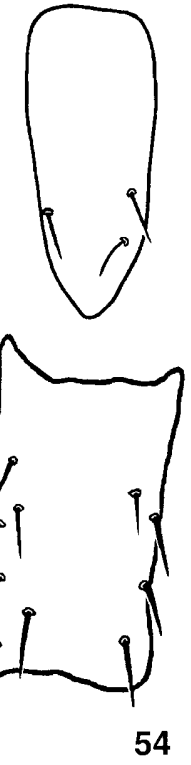

54

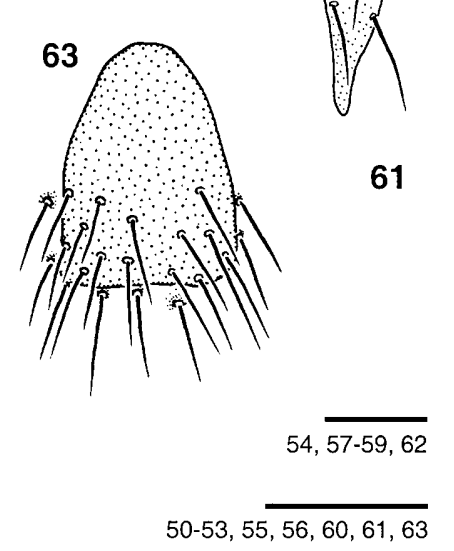

52

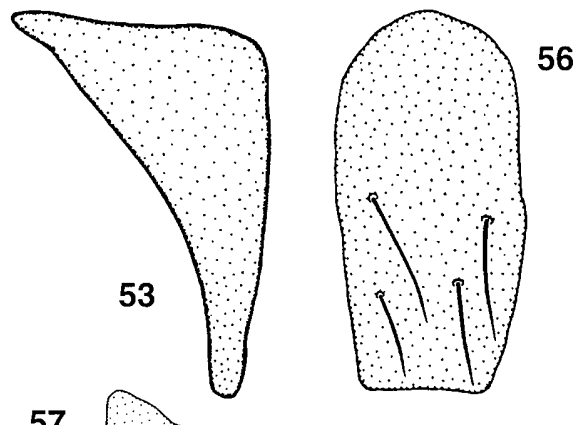

57
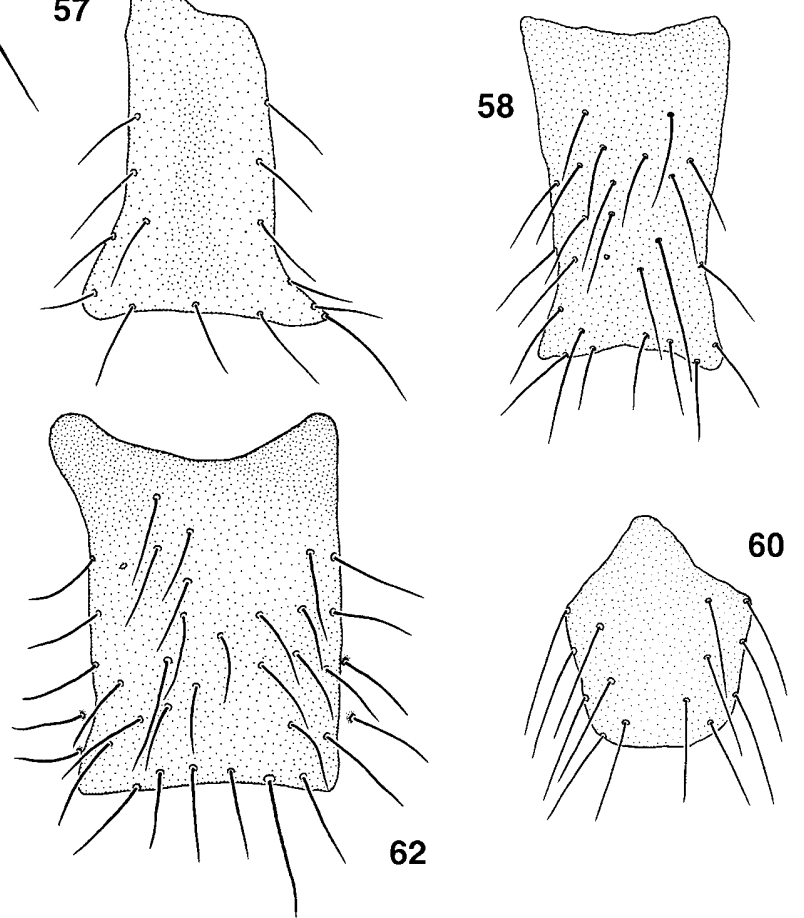

Figs 50-63. Female tergite 8 of Gymnophora spp. $50-$ G. gornostaevi sp. n.; $51-$ G. gotoi; $52-$ G. healyae; $53-$ G. integralis; $54-$ - G. multipinnacula; 55-56 - G. nigripennis; $57-$ G. pararcuata; $58-$ G. perpropinqua sp. n.; 59 - G. prescherweberae; $60-$ G. quartomollis; $61-$ - . victoria sp. n.; $62-$ - . sp. A; $63-$ - G. sp. B. Scale: 0.1 mm. (Fig. 51 courtesy of Dr. B.V. Brown, Fig. 52 courtesy of Dr R.H.L. Disney)

\section{Gymnophora sp. A}

(Figs $48,62,70,71$ )

\section{Description}

Female. Third antennal segment and palpi brown. Palpi just slightly broadened, hairy, with 3 apical and ventroapical bristles, which are 1.5 times as long as maximum palpus breadth, and with numerous shorter setae disposed medially, laterally, and ventrally. Mediolaterals just slightly longer than adjacent hairs. Notopleural ridge dark. Legs yellow brown. Wing length $3.79 \mathrm{~mm}$. Costal index 0.53. Costal sections ratio 9.41:1.47:1. Costa gradually thickened before $R_{1}$, with unusually long clear spot before $\mathrm{R}_{1}$, it is narrowed abruptly distad of this spot. Axillary ridge with 3 bristles. Halteres yellow. Abdominal T2 broad trapezoidal, T3-6 absent. Segment 5 with few short hairs in middle. Segment 6 with numerous hairs on dorsal face, which are longer along posterior margin; only short hairs developed in row along posterior margin on ventral face. T7 wedge-shaped, with irregular sides (Fig. 48), segment 7 hairy, with hairs being remarkably longer along posterior margin. S7 not developed. $\mathrm{T} 8$ generally rectangular, with strongly excavated anterior margin and slightly concave lateral and posterior margins, with numerous setae, which are somewhat longer on posterolateral corners (Fig. 62). Apical sclerites unusually wide and elongate, with short curly hairs arranged along posterior margin (Fig. 70). Cerci abruptly narrowed at midlength (Fig. 71). Abdominal glands small and poorly sclerotised although clearly visible; gland's opening between segments 5 and 6 distinct and bordered anteriorly with shagreened area.

Material examined. Russia: $1 \%$, Maritime Territory, Lazo Reserve, 10.vii. 1993 (Belokobyl'sky) (ZIN).

\section{Gymnophora sp. B}

(Figs 49, 63, 64)

\section{Description}

Female. Third antennal segment and palpi brown. Palpi not broadened, hairy, with 3 apical and ventro-apical bris- 

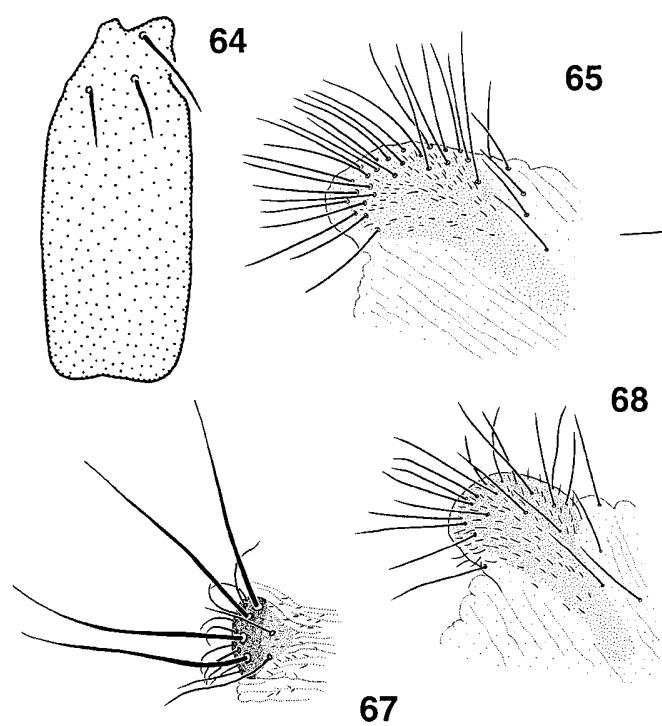

68

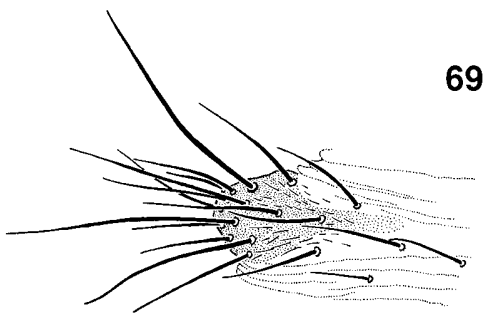

69
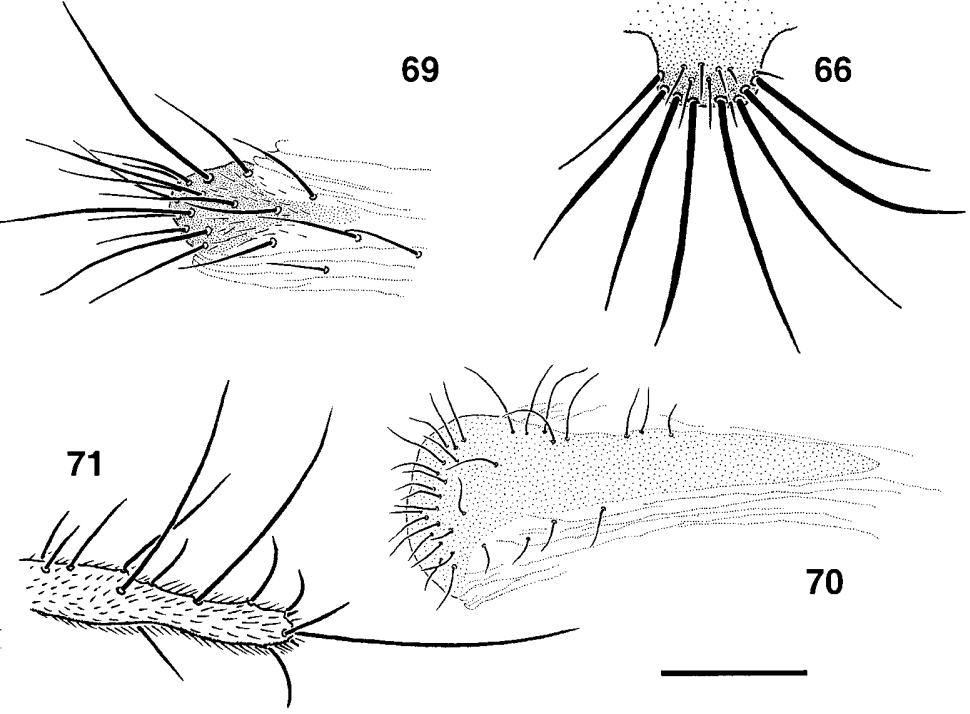

Figs 64-71. Details of female abdomen of Gymnophora spp. $64-$ G. sp. B, sternite 7; 65-70 - apical sclerites: $65-$ G. arcuata; 66-67-G. nigripennis; $68-$ G. perpropinqua sp. n.; $69-$ G. prescherweberae; $70-G$. sp. A; 71 - left cercus of $G$. sp. A. Scale: 0.1 mm.

tles, which are at least 2 times as long as maximum palpus breadth, and with numerous shorter setae medially, laterally and ventrally. Mediolaterals similar to other hairs on frons. Notopleural ridge dark. Legs yellowish brow. Wing length $3.36 \mathrm{~mm}$. Costal index 0.48. Costal sections ratio $6.02: 1.56: 1$. Costa gradually thickened before $R_{1}$. Axillary ridge with 3 bristles. Halteres yellow. Abdominal T2 broad trapezoidal, T3 developed as small rounded sclerite, T4 absent, T5 normally developed, wider than longer, T6 approximately as wide as long, with scattered short hairs in posterior half, $\mathrm{T} 7$ broad, parallel-sided (Fig. 49), S7 developed as broad plate (Fig. 64). Segment 7 with scattered hairs, those along posterior margin being 3-4 times as long as others. T8 triangular, with numerous setae in posterior half (Fig. 63). Apical sclerite single, with fan of long setae and numerous shorter hairs, which are arranged mainly along posterior margin. Cerci narrow, 4 times as long as wide, slightly tapered apically. Sclerotised abdominal glands absent.

Material examined. Russia: $1 \%$, Sakhalin Is., nr YuzhnoSakhalinsk, 19.vii.1955 (Violovich) (ZIN).

\section{KEY TO THE SPECIES OF GYMNOPHORA}

1. Males and females brachypterous .. G. lapidicola (Bezzi)

- Males and females macropterous .............. 2

2. Males ........................ 3

- Females ......................... 18

3. Costa abruptly thickened before $\mathrm{R}_{1}$ (Fig. 2) ....... 4

- Costa gradually thickened before $\mathrm{R}_{1}$ (Fig. 3) ....... 11

4. Left hypandrial process absent $\ldots \ldots \ldots \ldots \ldots \ldots 5$

- Left hypandrial process present, but sometimes may be poorly developed $\ldots \ldots \ldots \ldots \ldots \ldots \ldots \ldots \ldots$

5. Right side of epandrium with distinct notch (Fig. 12), hypoproct evidently longer than cerci and widened distally (Fig. 11) .................... G. gornostaevi sp. n.

- Right side of epandrium without such notch, hypoproct clearly shorter and not widened (Fig. 19)

G. multipinnacula Brown
6. Left hypandrial process strongly developed (e.g. Figs 9, 26,

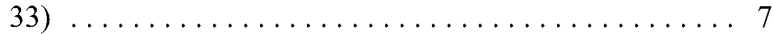

- Left hypandrial process small and sometimes developed only as tubercle $\ldots \ldots \ldots \ldots \ldots \ldots \ldots \ldots \ldots . \ldots$

7. Left hypandrial process swollen at mid-length, notopleural ridge pale $\ldots \ldots \ldots \ldots \ldots \ldots \ldots \ldots \ldots$

- Left hypandrial process not so, notopleural ridge pale or dark ................................

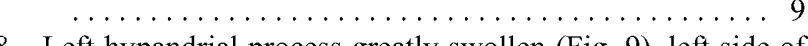

8. Left hypandrial process greatly swollen (Fig. 9), left side of epandrium with small ventral lobe (Fig. 8)

...................... G. arcuata (Meigen)

- Left hypandrial process only slightly swollen (Fig. 26), left side of epandrium with larger ventral lobe (Fig. 25) .....

\section{G. perpropinqua sp. n.}

9. Left hypandrial process rather broad and parallel-sided, left side of epandrium broader, with bristles and hairs along posterior margin, hypoproct longer than cerci (Fig. 18)

G. integralis Schmitz

- Left hypandrial process narrower and evenly tapered (Fig. 33), left side of epandrium remarkably narrower, with bristles arranged in posterodorsal fascicle (Fig. 31), hypoproct shorter than cerci (Fig. 32) ....... G. verrucata Schmitz

10. Notopleural ridge dark (Fig. 1), left side of epandrium with posterolateral elaboration, bristles despersed along posterior margin (Fig. 16), left hypandrial process developed as tubercle at most (Fig. 17) ......... G. healeyae Disney

- Notopleural ridge pale, left side of epandrium oblique, with distinct prominence bearing bristles arranged in bunch (Fig. 22), left hypandrial process more developed (Fig. 24) ....

G. pararcuata Brown

11. Gradual thickening of costa contains elongate clear spot before $\mathrm{R}_{1} \ldots \ldots \ldots \ldots \ldots$ presumed male of $\mathrm{sp} . \mathrm{A}$

- Costa without any clear spot .............. 12

12. Left hypandrial process entirely absent, cerci evidently short ............................... 14

- Left hypandrial process present, cerci longer ........ 13

13. Left side of epandrium elaborated posteriorly, with narrow ventral process, and with dispersed bristles (Fig. 14), basiphallus as Fig. 15 ............... G. gotoi Brown 
- Left side of epandrium oblique, without any ventral process, and with bristles arranged in row just below cerci (Fig. 4), basiphallus as Fig. 7 G. amurensis sp. $\mathrm{n}$.

14. Left side of epandrium with small posteroventral elaboration oriented either inwardly or outwardly (Figs 10, 21, 29)

- Left side of epandrium without such elaboration . . . . . 17

15. Posteroventral elaboration of left side of epandrium oriented outwardly, posterior margin of left side of epandrium clearly oblique (Fig. 21) . . . . . . . . . G. nigripennis Schmitz

- Posteroventral elaboration of left side of epandrium oriented inwardly, posterior margin of left side of epandrium less oblique or nearly straight $\ldots \ldots \ldots \ldots \ldots \ldots \ldots 16$

16. Posterior margin of left side of epandrium concave, only three to four bristles apart from tiny hairs on left face of epandrium, posteroventral elaboration somewhat triangular and attached farther from posterior margin (Fig. 29), bifurcate process (Fig. 30) clearly visible, when hypopygium viewed from left, mediolateral bristles on frons well differ from adjacent hairs, although they at least 2 times as weak as those on vertex .......... G. quartomollis Schmitz

- Posterior margin of left side of epandrium nearly straight or just slightly concave, left face of epandrium with more numerous bristles apart from tiny hairs, posteroventral elaboration rounded and attached closer to posterior margin (Fig. 10), bifurcate process hardly visible if aedeagal complex not removed, mediolaterals as weak as adjacent hairs on frons . . . . . . . . ...... G. fastigiorum Schmitz

17. Posterior margin of left side of epandrium more or less convex, without abrupt excavation or elaboration (Fig. 27), process of right side of epandrium with more or less rounded tip and notch near its tip when viewed from below, and with bristles arranged in sort of row (Fig. 28)

$\ldots \ldots \ldots \ldots \ldots \ldots$. . . prescherweberae Disney

- Posterior margin of left side of epandrium nearly straight with triangle ventral lobe and small tubercle just below cerci (Fig. 34), process of right side of epandrium notably drawn, with notch shifted far medially from its tip when viewed from below, and with dispersed bristles; distiphallus footshaped, heavily sclerotised and indented at posterior margin (Fig. 35) ................... G. victoria sp. n.

18. Tip of abdomen with single ventral sclerite . . . . . . 19 Tip of abdomen with paired ventral sclerites . . . . . . 29

19. Costa with abrupt thickening before $R_{1}$ (Fig. 2) . . . . . 20

- Costa gradually thickened before $\mathrm{R}_{1}$ (Fig. 3) ....... 26

20. Costal thickening with clear spot (Fig. 2) ....... 21

- Costal thickening without clear spot, or if present is obscure, $\mathrm{T} 7$ and $\mathrm{T} 8$ as Figs $39,52 \ldots \ldots \ldots$. healeyae Disney

21. Notopleural ridge dark (Fig. 1), abdomen with sclerotised paired glands $\ldots \ldots \ldots \ldots \ldots \ldots \ldots \ldots \ldots \ldots \ldots 22$

- Notopleural ridge pale, abdomen without sclerotised glands

22. T3-5 normally developed, internal abdominal glands discharge into a common chamber, whose opening to the exterior is enlarged and transversely elongated (Fig. 41), T7 with bristles arranged into two groups (Fig. 40), T8 crescent (Fig. 53) . .............. G. integralis Schmitz

- T5 always absent, T3 and 4 may be reduced or absent, opening of internal abdominal glands is much smaller and less conspicious, $\mathrm{T} 8$ is symmetrical . . . . . . . . 23

23. T7 more abruptly narrowing rearwards (Fig. 37), T8 elongate rounded triangular (Fig. 50), T3 nearly normally developed $\ldots \ldots \ldots \ldots \ldots \ldots \ldots$. gornostaevi sp. n T7 more gradually narrowing (Fig. 42), T8 mainly rectangular (Fig. 54), T3 reduced .... . G. multipinnacula Brown
24. T3 is more or less normally developed, or just slightly reduced, $\mathrm{T} 7$ with anterior margin being at most just slightly concave (Fig. 45), T8 symmetrical and generally rectangular (Fig. 58), clear spot on costa more rounded ........ 25

- T3 greatly reduced or entirely absent, anterior margin of T7 notably concave (Fig. 44), T8 with asymmetrical anterior portion (Fig. 57), clear spot on costa somewhat elongated

G. pararcuata Brown

25. Ventral apical sclerites of abdomen more rounded, with less number of setae (21-27), which are mostly not confined to the outer margin (Fig. 68), cerci ca. 5 times as long as broad G. perpropinqua sp. $\mathrm{n}$.

- Ventral apical sclerites of abdomen more elongated, with setae being more abundant (24-37) and mostly confined to the outer margin (Fig. 65), cerci usually more than 6 times as long as broad ............. arcuata (Meigen)

26. T3-6 entirely absent, only with hairs and setae on segments 5 and 6 , costa with greatly elongate clear spot, ventral apical sclerites broad, with short bent setae (Fig. 70), cerci abruptly narrowed at mid-length (Fig. 71), T7 and 8 as Figs $48,62 \ldots \ldots \ldots \ldots \ldots \ldots \ldots \ldots$. $\ldots$. . sp. A

- At least well defined T6 is always present, costa without any clear spot . . .................... 27

27. T3-6 normally developed, T7 broad (Fig. 47), T8 roughly crescent (Fig. 61) .............. G. victoria sp. nov.

- T3-5 always somewhat reduced, T7 narrower, T8 symmetrical

28. T8 is roughly as long as broad, with numerous setae (Fig. 59), $\mathrm{T} 7$ as Fig. 46, ventral apical plate as Fig. 69 ..... G. prescherweberae Disney

- T8 approximately 2 times as long as broad, with fewer setae (Fig. 51), T7 as Fig. $38 \ldots \ldots \ldots \ldots$. . . . gotoi Brown

29. T8 roughly triangular (Figs 55, 63) or otherwise (Fig. 56), but never broad pentagonal ............. 30

- T8 broad pentagonal (Fig. 60) ... G. quartomollis Schmitz

30. S7 developed as narrow sclerotised stripe, devoid of hairs or setae ........................... 31

- S7 broad, with several setae (Fig. 64), T7 and T8 as Figs 49, $63 \ldots \ldots \ldots \ldots \ldots \ldots \ldots \ldots \ldots \ldots \ldots \ldots \ldots$ sp. B

31. T7 watchglass-shaped (Fig. 36), T8 broad triangular similar to Fig. $63 \ldots \ldots \ldots \ldots \ldots$. . . . fastigiorum Schmitz - T7 wedge-shaped (Fig. 43), T8 otherwise or elongated if triangular (Figs 55, 56) ......... G. nigripennis Schmitz

ACKNOWLEDGEMENTS. We express our sincere thanks to E.P. Nartchuk, V.Ph. Zaitsev (ZIN), A.L. Ozerov (ZMMU), B.V. Brown (LACM), P. Vilkmaa (ZMUH), M. Baylac, J. Charbonnel (MNHN), B. Sinclair (ZFMK) for providing types and comparative material in their care, and to V. Kolyada (Moscow), who passed his collection of phorids for study. The senior author is grateful to A.Yu. Rozanov (Palaeontological Institute, Moscow) for arranging author's field trip to the Crimea in 1995, to P. Vrsansky (Comenius University, Bratislava and Paleontological Institute) for arranging an expedition to Transbaikalia under the project "AMBA" in 1997, and to M.N. Ovechkina (Palaeontological Institute) for valuable help in many ways. Our special thanks to Dr R.H.L. Disney (Cambridge University) for loan of material in his care, fruitful consultations, and viewing the manuscript. MBM's study of phorids is currently supported by the Royal Society/NATO Fellowship Programme.

\section{REFERENCES}

Brown B.V. 1987: Revision of the Gymnophora (Diptera: Phoridae) of the Holarctic Region: classification, reconstructed 
phylogeny and geographic history. Syst. Entomol. 12: 271-304.

BRown B.V. 1988: Testing phylogenetic hypotheses: new species of Gymnophora Macquart (Diptera: Phoridae) from Japan and Nepal, with an updated world classification. Can. J. Zool. 67: 2543-2556.

Brown B.V. 1998: New species and records of Gymnophora Macquart (Diptera: Phoridae) from Southeast Asia. Contributions in Science. Nat. Hist. Mus. Los Angeles County 471: $1-13$.

DisNeY R.H.L. 1980: A new species of Gymnophora Macquart (Diptera: Phoridae) from Yorkshire and Durham. Naturalist Hull. 105: 125-131.

Disney R.H.L. 1983: Scuttle flies - Diptera Phoridae (except Megaselia). Handbk Ident. Br. Insects 10: 1-81.

Disney R.H.L. 1994: Scuttle Flies: The Phoridae. London, Chapman \& Hall, 467 pp.

DISNEY R.H.L. 1997: A new species of Gymnophora (Dipt.: Phoridae) from Germany. Entomol. Mon. Mag. 133: 73-75.

DisNeY R.H.L. 1999: A troublesome sibling species complex of scuttle flies (Diptera: Phoridae) revisited. J. Nat. Hist. 33: $1159-1216$.
Liu G. 1993: A Taxonomic Study of Chinese phorid flies (Diptera: Phoridae). Northwestern Agricultural Univ., Yangling, Shaanxi, China, 195 pp.

Macquart J. 1835: Histoire Naturelle des Insectes. Diptères, Vol. 2, Paris, Roret, 703 pp.

MeIGEN J.W. 1830: Systematische Beschreibung der Bekannten Europaeischen Zweifluegeligen Insecten. Hamm. 6, iv +401 $\mathrm{pp}$.

MichailovsKaYA M.V. 1997: A review of the genus Gymnophora Macquart (Diptera: Phoridae) from the Russian Far East. Far East. Entomol. 45: 1-8.

Schmitz H. 1920: Die Phoriden von Hollaendisch Limburg. IV. Teil. Jaarb. Nat. Gen. Limb. 1919: 91-154.

Scrmitz H. 1926: Untersuchungen an Phoridentypen. Nat. Maandbl. 15: 19-24, 35-36, 43-48, 55-57.

SCHMITZ H. 1927: Revision der Phoridengattungen, mit Beschreibung neuer Gattungen und Arten. Nat. Maandbl. 16: $30-40,45-50,59-68,72-79,92-100,110-116,128-132$, $142-148,164,176$.

SCHMItZ H. 1952: Neue Arten von Gymnophora und Megaselia aus U.S.A. Brotéria 48: 177-188.

Received October 1, 2001; revised January 1, 2002; accepted October 14, 2002 